\title{
Phenotypic and genotypic variability between two Nigerian indigenous goat population
}

${ }^{1}$ Ojo, O. A., ${ }^{2}$ Akpa, G. N., ${ }^{3}$ Orunmuyi, M. and ${ }^{4}$ Adeyinka, I. A.

${ }^{I}$ National Agricultural Extension and Research Liaison Services, Ahmadu Bello University Zaria.

${ }^{2}$ Department of Animal Science, Ahmadu Bello University, Zaria

${ }^{3}$ Department of Animal Science, Federal University, Oye-Ekiti

${ }^{4}$ National Animal Production Research Institute

Ahmadu Bello University Zaria.

Abstract Corresponding Author: Kemiojo20@gmail.com; 09098619409

In order to estimate the future breeding potential of a livestock breed, it is necessary to estimate the level of genetic diversity within the breed. Thus, this study was conducted to determine the phenotypic and genotypic variability within the West African dwarf (WAD) goats and a non-descript goat population. The WAD goats were obtained from Bodija market Ibadan, Oyo state, while the non-descript goats were obtained from the Animal Science Departmental Farm in Zaria, Kaduna State. Random collection of tissue samples was carried out on each goat population using an all flex ear punch tissue sample collector and aliquoted into plastic tubes containing the all flex preservative. DNA extraction, amplification and sequencing were carried out at the International Livestock Research Institute (ILRI), Nairobi, Kenya. DNA was extracted from the tissue cells using the Pure Link ${ }^{\mathrm{TM}}$ Genomic DNA-minikit according to the manufacturer's specifications and protocol and 25 microsatellite markers as recommended by FAO/ISAG were used for genotyping. Twenty three of the 25 microsatellite markers used in this analysis had four or more alleles. The mean Shannon index (I), observed (Ho) and expected heterozygosity (He) and inbreeding coefficient $\left(F_{i s}\right)$ for the WAD goats were 1.568, 0.584, 0.679 and 0.167, respectively. For the non-descript goats, the mean Shannon index, observed and expected heterozygosity and inbreeding coefficient $\left(F_{i s}\right)$ were 1.607, 0.678, 0.721 and 0.041, respectively. The microsatellite markers used in this study showed their suitability for analysis of genetic variability in this population as demonstrated by the high mean Shannon index. This study has shown that these two goat populations are significantly different phenotypically and genetically. Also, both populations showed significant deviations $(P<0.01)$ from Hardy-Weinberg expectations.

Keywords: Nigerian Indigenous goats, phenotypic traits, microsatellite markers, heterozygosity

\section{Introduction}

Developing countries such as Nigeria hosts a vast majority of indigenous farm animal genetic resources (over 90\%), that unfortunately have not being improved to respond to global food security needs (FAO, 1999). One of the primary goals in the management of animal populations is to maintain their genetic diversity at a high level and their inbreeding at a low level
(Fernández et al., 2005). To estimate the future breeding potential of a livestock breed, it is necessary to estimate the level of genetic diversity within the breed. For this purpose genetic materials are used (Saitbekova et al., 1999; Dasmahapatra et al., 2008). From genetic material, microsatellite markers are commonly used to describe the genetic polymorphism (Saitbekova et al., 1999; Luikart et al., 
2001; Naderi et al., 2007; Agha et al., 2008). Microsatellite markers are widely used for the analysis of genetic variability within and between breeds due to their polymorphism, distribution throughout the genome and efficacy of genotyping (Barker et al., 1997; Chenyambuga et al., 2004, Okpeku et al., 2011). There are several studies on genetic variability of goats, based on microsatellite markers, such as Swiss breeds (Saitbekova et al., 1999), Chinese indigenous populations (Li et al., 2002; Li et al., 2004), Indian domestic goats (Rout et al., 2008), goats from Europe and middle east (Canon et al., 2006). Very scanty studies have been carried out on the genetic diversity of Nigerian indigenous goats (Adebambo et al., 2011; Okpeku et al., 2011; Ojo, 2014; Yakub et al., 2014).

\section{Materials and methods}

Tissue samples from 80 unrelated individual goats from the two goat populations were used for this study. The WAD goats were obtained from Bodija market in Oyo State, while the non-descript goats were sampled from Animal Science Departmental Farm, Ahmadu Bello University, Samaru, Zaria. Eighty goats were randomly sampled from both sexes. Tissue samples were collected using an all flex ear punch tissue sample collector and aliquoted into plastic tubes containing the all flex preservative. The DNA extraction, amplification and sequencing were carried out at the International Livestock Research Institute (ILRI), Nairobi, Kenya. The DNA extraction from the tissue cells was carried out using the Pure Link ${ }^{\mathrm{TM}}$ Genomic DNA minikit according to the manufacturer's specifications and protocol. Twenty five microsatellite markers were used in this study as recommended by the International Society for Animal Genetics and Food and Agricultural Organization (FAO, 2011).

\section{Polymerase Chain Reaction (PCR) Conditions}

The PCR typing was carried out on 50ng of the genomic DNA in a $10 \mu \mathrm{L}$ reaction, comprising $10 \mathrm{pM}$ each of fluorescently labeled PCR primers, $1 \mu \mathrm{L}$ of PCR buffer (Amersham) $20 \mu \mathrm{M}$ each of dCTP, dGTP, dTTP and dATP, 0.5 units of Taq polymerase per reaction and $1.5-3.0 \mu \mathrm{L}$ of $\mathrm{MgCl} 2$ depending on the primer. The mixture was cycled on the Hybaid Omnigene thermal cycler with cycling conditions of initial denaturation at $95^{\circ} \mathrm{C}(4$ minutes), annealing at $50-65^{\circ} \mathrm{C}$ for 45 seconds and final extension at $72^{\circ} \mathrm{C}(15$ minutes) for 35 cycles.

Multiplexing was carried out following the recommendations of the ISAG/FAO panel. Genotyping was done using the ABI 3700XL automated capillary sequencer using Liz 500-350 internal lane size standard to size fractionate all amplified products. Allele size calling and binding was done with the aid of Gene Mapper 3.5 (Applied Bio systems).

\section{Statistical analysis}

The allele frequencies, observed and expected heterozygosities, genetic distance as well as genetic differentiation were computed using Gen Alex 6.5 genetic analysis statistical package (Peakall and Smouse, 2012).

\section{Results and discussion}

The results of descriptive statistics of the phenotypic traits (body length, height at withers, and chest girth) of the WAD and the non-descript goat populations are revealed in Table 1 . The analysis of variance showed significant $(\mathrm{P}<0.01)$ differences in all the measured traits. The non-descript goats showed higher means and variances in all the traits considered compared to the WAD goats. The significant differences observed between 


\section{Ojo, Akpa, Orunmuyi and Adeyinka}

the goat breeds suggest a direct relationship between the extent of morphometric divergence and geographical separation. This is in accordance with the results of Brown et al. (2006) that temporal and spatial variation in weather, plant productivity and subsequent nutrition could have major impacts on physical growth of animals. Also, the results obtained from the coefficients of variation as well as variance could be attributed to breed differences, influence of environmental factors on the measured parameters especially the width measurements.

Table 1: Descriptive statistics of the phenotypic traits of West African dwarf (WAD) and a Non-descript goat population

\begin{tabular}{llll}
\hline Trait & WAD Goat & $\begin{array}{l}\text { Non-descript goat } \\
\text { Population }\end{array}$ \\
\hline $\mathrm{BL}$ & Mean \pm s.e & $52.97 \pm 0.84^{\mathrm{b}}$ & $59.90 \pm 0.56^{\mathrm{a}}$ \\
& $\mathrm{S}^{2}$ & 42.71 & 6.20 \\
$\mathrm{HW}$ & $\mathrm{CV}$ & 12.34 & 4.16 \\
& Mean \pm s.e & $55.88 \pm 0.84^{\mathrm{b}}$ & $59.20 \pm 0.75^{\mathrm{a}}$ \\
& $\mathrm{S}^{2}$ & 41.87 & 11.12 \\
$\mathrm{CG}$ & $\mathrm{CV}$ & 11.58 & 5.63 \\
& $\mathrm{Mean} \pm$ s.e & $55.87 \pm 0.94^{\mathrm{b}}$ & $62.65 \pm 0.66^{\mathrm{a}}$ \\
& $\mathrm{S}^{2}$ & 52.49 & 8.66 \\
& $\mathrm{CV}$ & 12.97 & 4.70 \\
\hline
\end{tabular}

BL- body length, HW- height at withers, CG- chest girth.

s.e-standard error; $\mathrm{S}^{2}$ - variance; $\mathrm{CV}$ - coefficient of variation ${ }^{\mathrm{a}}, \mathrm{b}, \mathrm{c}$

${ }^{\text {ab }}$ Means in the same row with different superscripts are significantly different at $\mathrm{P}<0.05$

Table 2 shows the number of effective alleles $(\mathrm{Ne})$, observed (Ho) and expected $(\mathrm{He})$ heterozygosity and fixation index for (I) the WAD goat population. The markers used in this population were highly informative with allelic numbers ranging from 3 for ILSTS005 to 19 for BM6444. The highest value obtained for the effective alleles in this population was 8.571 (SRCSP 9) while the least was 1.116 (ILSTS 005). The observed heterozygosities (Ho) ranged from 0.027 (MAF 65) to 1.000 (SPS 113), while the expected heterozygosity $(\mathrm{He})$ ranged from 0.104 (ILSTS 005) to 0.883 (SRCSP 9). The Shannon index (I) ranged from 0.236 to 2.429 and in most cases were higher than 1.0. The inbreeding index $\left(\mathrm{F}_{\text {is }}\right)$ was negative at six (6) loci (ILSTS029, ILSTS087, SPS113, SRYM18, OarFCB34 and MAF209) displaying some level of out-breeding at such loci and was positive (inbred) for the remaining loci ranging from 0.033 (OarFCB48) to 0.854 (INRABERN172).
The number of effective alleles $(\mathrm{Ne})$, observed (Ho) and expected heterozygosity $(\mathrm{He})$, Shannon (I) and fixation index $\left(\mathrm{F}_{\mathrm{is}}\right)$ using the 25 microsatellite markers for the non-descript goat population are revealed in Table 3. The number of available alleles ranged from 2-14. The highest value obtained for the effective allele was 8.989 (ILSTS 087) while the least was 1.133 (ILSTS 005). The observed heterozygosity (Ho) ranged from 0.125 (ILST 005) to 1.000 (SPS 113 and SRYM 18), while the expected heterozygosity $(\mathrm{He})$ ranged from 0.117 (ILSTS 005) to 0.889 (ILST 087 and MAF 65). Most of the primers/markers used for this population were informative and displayed sufficient polymorphism in markers with the exception of ILSTS 005 and INRABERN 185 which had allele numbers of 2 and 3 , respectively. 
Table 2: Allelic Frequencies (Na, Ne), Shannon Index (I) Heterozygosity (Ho, He) and F-statistics

\begin{tabular}{|c|c|c|c|c|c|c|c|}
\hline \multicolumn{8}{|c|}{$\left(F_{\text {is }}\right)$ in West African dwarf Goats } \\
\hline Locus & $\mathbf{N}$ & $\mathrm{Na}$ & $\mathrm{Ne}$ & I & Ho & $\mathrm{He}$ & $F_{\text {is }}$ \\
\hline OarFCB20 & 32 & 7.000 & 4.188 & 1.657 & 0.594 & 0.761 & 0.220 \\
\hline BM6444 & 60 & 19.000 & 8.036 & 2.429 & 0.783 & 0.876 & 0.105 \\
\hline CSRD247 & 56 & 8.000 & 5.733 & 1.876 & 0.732 & 0.826 & 0.113 \\
\hline ETH10 & 60 & 15.000 & 4.417 & 1.948 & 0.533 & 0.774 & 0.311 \\
\hline ILSTS005 & 55 & 3.000 & 1.116 & 0.236 & 0.073 & 0.104 & 0.300 \\
\hline ILSTS11 & 43 & 12.000 & 3.365 & 1.705 & 0.651 & 0.703 & 0.073 \\
\hline ILSTS029 & 60 & 11.000 & 2.601 & 1.380 & 0.683 & 0.616 & -0.110 \\
\hline ILSTS087 & 60 & 14.000 & 8.072 & 2.227 & 0.900 & 0.876 & -0.027 \\
\hline INRA023 & 41 & 10.000 & 5.086 & 1.837 & 0.634 & 0.803 & 0.211 \\
\hline INRABERNI185 & 36 & 5.000 & 1.468 & 0.701 & 0.250 & 0.319 & 0.215 \\
\hline INRABERN172 & 25 & 9.000 & 5.580 & 1.950 & 0.120 & 0.821 & 0.854 \\
\hline MAF65 & 37 & 4.000 & 1.214 & 0.403 & 0.027 & 0.176 & 0.847 \\
\hline MAF70 & 59 & 9.000 & 4.284 & 1.711 & 0.746 & 0.767 & 0.027 \\
\hline MCM527 & 60 & 5.000 & 2.374 & 1.171 & 0.267 & 0.579 & 0.539 \\
\hline OarFCB48 & 60 & 11.000 & 3.411 & 1.598 & 0.683 & 0.707 & 0.033 \\
\hline OarFCB304 & 59 & 13.000 & 3.920 & 1.756 & 0.644 & 0.745 & 0.135 \\
\hline SPS113 & 60 & 10.000 & 2.684 & 1.264 & 1.000 & 0.627 & -0.594 \\
\hline SRCRSP3 & 60 & 5.000 & 3.216 & 1.294 & 0.550 & 0.689 & 0.202 \\
\hline SRCSP9 & 58 & 10.000 & 8.571 & 2.207 & 0.707 & 0.883 & 0.200 \\
\hline SRYM18 & 60 & 16.000 & 4.672 & 2.021 & 0.967 & 0.786 & -0.230 \\
\hline TCRVB6 & 44 & 9.000 & 2.076 & 1.235 & 0.386 & 0.518 & 0.255 \\
\hline OarPC34 & 48 & 9.000 & 5.075 & 1.841 & 0.813 & 0.803 & -0.012 \\
\hline SRCSP5 & 59 & 12.000 & 6.574 & 2.046 & 0.678 & 0.848 & 0.200 \\
\hline MAF209 & 60 & 6.000 & 4.162 & 1.480 & 0.767 & 0.760 & -0.009 \\
\hline INRA063 & 58 & 6.000 & 2.530 & 1.176 & 0.414 & 0.605 & 0.316 \\
\hline Mean & 52.400 & 9.520 & 4.177 & 1.568 & 0.584 & 0.679 & 0.167 \\
\hline SE & 2.149 & 0.796 & 0.417 & 0.110 & 0.054 & 0.041 & 0.059 \\
\hline
\end{tabular}

$\mathrm{N}=$ sample size, $\mathrm{Na}=$ no. of alleles, $\mathrm{Ne}=$ no.of effective alleles, $\mathrm{I}=$ Shannon index, $\mathrm{Ho}=$ observed heterozygosity, $\mathrm{He}=$ expected heterozygosity and $F_{\text {is }}=$ fixation index/inbreeding coefficient.

The Shannon index (I) for this population ranged from 0.234 to 2.395 . The ILSTS005 marker had low Shannon index (0.234) and number of alleles, whereas the inbreeding index $\left(\mathrm{F}_{\text {is }}\right)$ ranged between ( -0.012 to 0.444$)$ and were negative at eleven loci for this population (BM6444, ILSTS005, IL STS 11, ILSTS029, IL S TS 087 , INRABERN185, OarFCB304, SPS113, SRYM18, SRCSP9, TCRVB6).

In both of the goat populations, the marker ILSTS005 was observed to have low polymorphism (allelic numbers below 4).
Some measure of out-breeding was observed in both populations as recorded by the negative $F_{\text {is }}$ values. These homozygous deficiencies may have arisen from population sub-division owing to genetic drift, null alleles and selection against inbreeding. These negative values have also been reported in other studies on goats (Barker et al., 1997, Luikart et al., 1999, Agha et al., 2008, Rout et al., 2008, Dixit et al., 2009)

Table 4 revealed the average observed and expected heterozygosities of the two goat 


\section{Ojo, Akpa, Orunmuyi and Adeyinka}

Table 3: Allelic Frequencies (Na, Ne), Shannon Index (I), Heterozygosity (Ho, He) and F-statistics $\left(F_{\text {is }}\right)$ in a Non-descript goat population

\begin{tabular}{llrllllr}
\hline Locus & $\mathbf{N}$ & \multicolumn{1}{c}{$\mathbf{N a}$} & $\mathbf{N e}$ & $\mathbf{I}$ & $\mathbf{H o}$ & $\mathbf{H e}$ & $\mathbf{F}_{\text {is }}$ \\
\hline OarFCB20 & 14 & 5.000 & 4.170 & 1.509 & 0.429 & 0.760 & 0.436 \\
BM6444 & 20 & 8.000 & 2.676 & 1.331 & 0.750 & 0.626 & -0.198 \\
CSRD247 & 19 & 9.000 & 5.870 & 1.933 & 0.789 & 0.830 & 0.048 \\
ETH10 & 20 & 13.000 & 7.143 & 2.235 & 0.650 & 0.860 & 0.244 \\
ILSTS005 & 16 & 2.000 & 1.133 & 0.234 & 0.125 & 0.117 & -0.067 \\
ILSTS11 & 18 & 8.000 & 2.521 & 1.307 & 0.722 & 0.603 & -0.197 \\
ILSTS029 & 20 & 4.000 & 1.891 & 0.899 & 0.500 & 0.471 & -0.061 \\
ILSTS087 & 20 & 14.000 & 8.989 & 2.394 & 0.950 & 0.889 & -0.069 \\
INRA023 & 16 & 8.000 & 4.876 & 1.793 & 0.750 & 0.795 & 0.057 \\
INRABERNI185 & 13 & 3.000 & 1.807 & 0.733 & 0.615 & 0.447 & -0.377 \\
INRABERN172 & 17 & 11.000 & 6.494 & 2.104 & 0.471 & 0.846 & 0.444 \\
MAF65 & 8 & 9.000 & 8.000 & 2.133 & 0.750 & 0.889 & 0.143 \\
MAF70 & 18 & 6.000 & 3.447 & 1.448 & 0.611 & 0.710 & 0.143 \\
MCM527 & 20 & 4.000 & 2.432 & 1.074 & 0.500 & 0.589 & 0.151 \\
OarFCB48 & 20 & 9.000 & 6.612 & 2.005 & 0.650 & 0.849 & 0.234 \\
OarFCB304 & 20 & 10.000 & 6.250 & 2.048 & 0.850 & 0.840 & -0.012 \\
SPS113 & 20 & 8.000 & 3.774 & 1.586 & 1.000 & 0.735 & -0.361 \\
SRCRSP3 & 17 & 5.000 & 3.524 & 1.352 & 0.647 & 0.716 & 0.097 \\
SRCSP9 & 20 & 7.000 & 4.348 & 1.622 & 0.800 & 0.770 & -0.039 \\
SRYM18 & 20 & 12.000 & 7.767 & 2.220 & 1.000 & 0.871 & -0.148 \\
TCRVB6 & 12 & 7.000 & 5.143 & 1.772 & 0.833 & 0.806 & -0.039 \\
OarPC34 & 14 & 7.000 & 4.840 & 1.729 & 0.643 & 0.793 & 0.190 \\
SRCSP5 & 19 & 10.000 & 6.067 & 1.972 & 0.737 & 0.835 & 0.118 \\
MAF209 & 20 & 6.000 & 3.941 & 1.530 & 0.600 & 0.746 & 0.196 \\
INRA063 & 17 & 5.000 & 2.861 & 1.209 & 0.588 & 0.651 & 0.096 \\
Mean & 17.520 & 7.600 & 4.663 & 1.607 & 0.678 & 0.721 & 0.041 \\
SE & 0.638 & 0.611 & 0.425 & 0.104 & 0.038 & 0.035 & 0.041 \\
\hline
\end{tabular}

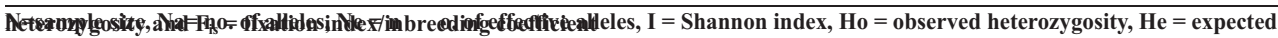

populations as well as their HardyWeinberg equilibrium values. The average expected heterozygosity was lower in WAD goats $(0.679)$ as compared with the Nondescript goats (0.721). Also, the Nondescript goats had higher observed heterozygosity (0.678) than the WAD goat (0.568). In both cases, the average observed heterozygosities were lower than the expected heterozygosities and both populations showed significant deviations $(\mathrm{P}<0.01)$ from Hardy-Weinberg expectations.

Table 4: Hardy -Weinberg Equilibrium for the Two Nigerian goat populations

\begin{tabular}{|c|c|c|c|c|}
\hline Populations & Ho & He & HWE & . \\
\hline $\begin{array}{l}\text { Non-descript goat } \\
\text { population }\end{array}$ & 0.678 & 0.721 & 0.0026 & $* *$ \\
\hline $\begin{array}{l}\text { West African } \\
\text { Dwarf }\end{array}$ & 0.568 & 0.679 & 0.0133 & $* *$ \\
\hline
\end{tabular}


The significant deviations from the HardyWeinberg Equilibrium for the two goat populations, implies that there was a deficit of heterozygosity resulting from the nonrandom union of gametes in the population i.e. the mating among individuals in the population which are more related than the average relationship. Similarly, migration, mutation and selection might have caused these deviations. Deviations from HardyWeinberg equilibrium at microsatellite level have been reported in various studies (Barker et al., 2001; Hassan et al., 2003; Laval et al., 2000; Luikart et al., 1999).

\section{Conclusion}

This study has shown that there are significant phenotypic differences between the West African dwarf goat and the nondescript goat from Zaria. Also, most of the primers/markers used for this population were highly informative and displayed sufficient polymorphism. Significant deviations from the Hardy -Weinberg Equilibrium were observed in the two goat populations.

\section{Recommendations}

Improved conservation and management practices, which could ensure uniqueness of the individual goat populations and avoid inbreeding, should be implemented.

\section{References}

Adebambo, A. O. Adebambo, O. A., Williams, J. L., Blott, S. and Urquart, B. 2011. Genetic distance between two popular Nigerian goat breeds used for milk production. Livestock Research for Rural Development 23(2), 1-6.

Agha, S. H., Pilla, F., Galal, S., Shaat, I., D'Andrea, M., Reale, S., Abdelsalam, A. Z. A. and Li, M. H. 2008. Genetic diversity in
Egyptian and Italian goat breeds measured with microsatellite polymorphism. Journal of Animal Breeding and Genetics 125; 194200.

Barker, J. S. F., Moore, S. S., Hetzel, D. J. S., Tan, S. G. and Byrne, K. 1997. Genetic diversity of Asian water buffalo (Bubalusbubalis): microsatellite variation and a comparison with protein coding loci. Animal Genetics, 28: 103115.

Barker, J. S. F., Tan, S. G., Moore, S. S., Mukherjee, T. K., Matheson, J. L. and Selvaraj, O. S. 2001. Genetic variation within and relationships among populations of Asian goats (Capra hircus). Journal of Animal Breeding and Genetics 118(4), 213-233.

Brown, D. E., Maher, C. R. and Mitchell, C. D. 2006. A comparison of Pronghorn body measurements throughout North- Western America. Proceedings of the 22nd Biennial Pronghorn Workshop, USA. PP. 125-137.

Cañon, J., Garcia, D., Garcia-Atance, M. A., Obexer- Ruff, G., Lenstra, J. A., Ajmone- Marsan, P., Dunner, S. and Econogene Consortium 2006. Geographical partitioning of goat diversity in Europe and the Middle East. Animal Genetics, 37; 327-334.

Chenyambuga, S. W., Hanotte, O., Watts, P. C., Kemp, S. J., Kifaro, G. C., Gwakisa, P. S., Petersen, P. H. and Rege, J. E. 2004. Genetic characterization of indigenous goats of Sub-Saharan Africa using Microsatellite DNA markers. Asian -Australian Journal of Animal Science 17 (4): 445-452. 
Dasmahapatra, K. K., Lacy, R. C. and Amos, W. 2008. Estimating levels of inbreeding using AFLP markers. Heredity, 100 (3): 286295.

Dixit, S. P., Verma, N. K., Aggarwal, R. A. K., Kumar, S., Chander, R., Vyas, M. K. and Singh, K. P. 2009. Genetic structure and differentiation of three Indian goat breeds. Asian - Australian Journal of Animal Science. 22(9): 12341240.

FAO, 1999. The global strategy of the management of Farm Animal Genetic Resources. Executive Brief. FAO, Rome.

Fernández, J., Villanueva, B., PongWong, R. and Toro, M. A. 2005. Efficiency of the use of pedigree and molecular marker information in conservation programs. Genetics, Selection and Evolution, 170: 1313-1321.

Hassan, A. A., Abou, M. H. A., Oraby, H. A., De Hondt E. L. and Nahas, S. M. 2003. Genetic diversity of three sheep breeds in Egypt based on micro-satellite Analysis. Journal of Engineering Biotechnology, (NRC) 1 (1): 141-150.

Laval, G., Iannuccelli, N., Legault, C., Milan, D., Groenen, M. A., Giuffra, E., Andersson, L., Nissen, P. H., Jorgensen, C. B., Beeckmann, P., Geldermann, H., Foulley, J. L., Chevalet, C. and Ollivier, L. 2000. Genetic diversity of eleven European pig breeds.Genetics, Selection and Evolution 32(2), 187-203.

Li, M. H., Zhao, S. H., Bian, C., Wang, H. S., Wei, H., Liu, B., Yu, M., Fan, B., Chen, S. L.,Zhu, M. J., Li, S. J., Xiong, T. A. and Li, K. 2002.
Genetic relationships among twelve Chinese indigenous goat populations based on microsatellite analysis. Genetics, Selection and Evolution 34(6), 729-744.

Li Xiang-Long and Valentini, A. 2004. Genetic diversity of Chinese goat breeds based on microsatellite markers. Journal of Animal Breeding and Genetics. 121:350355.

Luikart, G., Biju-Duval, M.P. Ertugrul, O., Zagdsuren, Y., Maudet, C. and Taberlet, P. 1999. Power of 22 microsatellite markers in fluorescent multiplexes for parentage testing in goats (Capra hircus). Animal Genetics, 30: 431438.

Luikart, G., Gielly, L., Excoffier, L., Vigne, J. D., Bouvet, J. and Taberlet, P. 2001. Multiple maternal origins and weak phylogeographic structure in domestic goats. Proceedings of Natural Academic Sciences. U. S. A. 98(10): 5927-32.

Naderi, S., Razaei, H. R., Taberlet, P., Zundei, S., Rafat, S. A. and Naghash, H. R. 2007. Large-Scale Mitochondrial DNA Analysis of the Domestic Goat Reveals Six Haplogroups with High Diversity. PLoS ONE, (10): 1-12.

Ojo, O. A 2014. Genetic Diversity of Nigerian Indigenous Goat Breeds using Microsatellite Markers. A Ph.D. dissertation Ahmadu Bello University Zaria, Nigeria.

Okpeku, M., Peters, S. O., Ozoje, M. O., Adebambo, O. A., Agaviezor, B. O., O'Neill, M. J. and Imumorin, I. G. 2011. Preliminary analysis of microsatellite -based genetic 
diversity of goats in Southern Nigeria. Animal genetic resources 49:33-41.

Rout, P. K., Joshi, M. B., Mandal, A., Laloe, D., Singh, L. and Th a n g a r a j, K. 2008 . Microsatellite based phylogeny of Indian domestic goats. Doi: 10.1186/1471-2156-9 11.BMCGenetics 9; 11.

Saitbekova, N., Gaillard, C., ObexerRuff, G. and Dolf, G. 1999. Genetic diversity in Swiss goat breeds based on microsatellite analysis. Animal Genetics 30(1): 36- 41.
Yakubu, A., Salako, A. E., Akinyemi, M. O. and Abdullah, A. R. 2014. Genetic Characterization of NonDescript goats in Nasarawa State, Nigeria using Microsatellite Markers: A Preliminary Investigation. Proceedings of $39^{\text {th }}$ Conference of Nigerian Society for Animal Production 16-19 March 2014.

Received: 14th November, 2017 Accepted: 18th Februrary, 2018 